\title{
ADVANCING WELL-BEING WITH INTEREST-FREE FINANCE
}

\author{
Abdul Karim Abdullah *
}

\begin{abstract}
This paper argues that utilising risk sharing in preference to interestbased financing would bring a broad range of economic benefits to both individuals and society. The main reason is that equity financing, whether in its conventional or Islamic form, allocates resources more efficiently than loan financing. To show this, the paper compares equity markets with credit markets with a view to efficiency. The prime reason why equity markets allocate resources better than credit markets is that profit as an incentive for driving economic activity is far better suited for allocating resources efficiently than interest. The paper concludes with a number of policy recommendations.
\end{abstract}

\section{Benefits of guidance}

Islam teaches that compliance with revealed guidance brings success while defiance brings failure. History confirms the truth of this principle. The prohibition of interest (usury) is one of the major prohibitions in the Qur'an. Yet interest has been legalised in a number of nations. ${ }^{1}$

The social acceptance of usury enabled the entrenchment of a different culture, radically unlike what preceded it. Over the course of history, the practice of usury has brought untold misery. Poverty, inequality, indebtedness, and even debtors' prisons testify to the harsh consequences of usury. Few practices have caused and continue to cause as much harm.

It is no doubt on account of the misery and hardship it causes for countless persons that usury (interest) is prohibited in the Qur'an. For the realisation of justice is one of the main objectives of the Shariah. However, the practice of usury threatens other objectives of the Shariah as well, such as the protection of wealth.

The harm caused by interest-based lending manifests itself not only in the pervasive indebtedness of individuals, companies and entire nations. ${ }^{2}$ It also manifests itself in the suffering caused to millions by the need to pay interest. ${ }^{3}$

Large and in some cases growing levels of debt are not sustainable over the longer term. ${ }^{4}$ Indebtedness of nations such as Greece is only one manifestation of the global debt crisis. ${ }^{5}$ Lending at interest favours the wealthy at the expense of the poor, whether individuals or nations. ${ }^{6}$

Financing expenditure by means of interest-based loans imposes burdens on people and society in different ways. High levels of consumer indebtedness 
caused by excessive spending and the risk of getting mired in a debt trap are only some of the consequences of borrowing. ${ }^{7}$ However, interest-based financing also has a number of adverse macroeconomic effects.

The use of interest-based financing adds to unemployment, worsens inflation, and increases the gap between the rich and poor. In all these ways, the use of interest-based financing causes injustice. ${ }^{8}$ Financial instability, business cycles, as well as reduced economic growth over the longer term are also attributable to the use of interest-based financing. ${ }^{9}$

By contrast, interest-free methods of financing expenditure such as risk sharing prevent harm and bring benefits. Thus, it is necessary to take steps to supplant lending at interest by other forms of financing, in particular risk sharing.

The conventional view, however, is that interest-based financing in fact helps society. It does this by channelling surplus funds (savings) to investors (in the form of loans) and by rationing funds to the most efficient or profitable businesses.

However, surplus funds can also be channelled into investment by means of interest-free, participatory contracts. Moreover, the most efficient businesses are not necessarily always the same as the most profitable ones.

In the sales of consumer products, interest-free financing can be implemented by encouraging manufacturers to sell their products directly to customers, on an instalment (credit) basis, without the costly "intermediation" by financial institutions. However, in order to prevent opening the proverbial "back door to riba," the credit price of the products would have to be the same as the cash price. ${ }^{10}$

Implementing direct selling on an industry-wide basis would require amending the law to enable manufacturers to provide interest-free financing. A small administrative charge, set by the government, could be added to the cash price of the item in order to compensate sellers for any extra expenses they might incur from administering sales on an instalment (credit) basis. ${ }^{11}$

The acceptance of interest as a morally and legally acceptable incentive for rewarding investment was facilitated by adopting the view that interest is little different from profit as a driver of commercial activity and therefore equally suitable as an incentive for an efficient allocation of resources.

\section{Interest and profit}

A closer look at interest and profit shows that important differences exist between these two incentives for engaging surplus capital in economic activity. These differences have profound effects on how resources are allocated in the economy, as well as on how the fruits of economic activity are distributed within society. In the case of profits, the effects are positive. In the case of interest, they are harmful. ${ }^{12}$ 
The major difference between interest and profit is that while the amount of profit earned by investors is closely linked to the performance of a business enterprise, interest income is not tied in any way to the performance of a business being financed with loans.

On the contrary, all interest payments are determined in advance, and moreover must be legally guaranteed by the borrowers. This means that lenders, unlike investors, have no incentive to channel resources into projects that offer returns higher than what it takes to repay all loans with interest.

Determining the amount of interest owing to lenders independently of any profits earned is made possible by the fact that the amount of interest paid to lenders depends on the amount of the loan made by lenders to entrepreneurs, and on the percentage of interest charged on the loan, rather than on the amount of profit earned by entrepreneurs.

In other words, in loan financing interest is calculated as a percentage of the total amount loaned, which is known in advance, while in equity financing profits are calculated as a proportion of total profits earned, which are not known in advance. It is for this reason that profits can never be determined in advance. They can only be projected.

Moreover, borrowers are legally obliged to guarantee both the interest and the principal amount of the loan to lenders. By contrast, entrepreneurs are obliged to guarantee neither profits nor the capital invested. The reason is that unlike lenders, investors are obliged to take risk.

The need to take risk provides investors with a strong incentive to exercise due diligence before investing in any project. Exercising due diligence in turn helps to allocate resources more efficiently, as only viable projects will attract funding.

The use of interest-based lending has contributed to the financial crises, with each crisis being greater than its predecessor. The cost of each upheaval, in the form of "bailing out" financial institutions, has been rising at an exponential rate. How long can the process of reflating economies with injections of liquidity continue? ${ }^{13}$ How long is re-financing debt with more debt "sustainable"? ${ }^{14}$

Because of its harmful effects, eliminating interest from economic transactions can bring significant benefits. These benefits would enhance social welfare and ensure higher efficiency with which resources are allocated among alternative uses. $^{15}$

Financing without interest is possible. Globally, approximately one third of financing takes place on the basis of risk sharing. Equity financing has been around for centuries, even if its proportion out of total financing has declined, especially beginning the latter half of the twentieth century. 


\section{Need for a better paradigm}

Theories, models or analytical frameworks are used to study problems and recommend policy responses to them, whether in the public sector or in business. For a theoretical model to be reliable, it needs to have a solid foundation.

This foundation typically takes the form of underlying assumptions about how a given system works and what can be expected from it. Such models can be found in the sciences, both social and natural.

Thus, a theory can only be as reliable as the underlying assumptions on which it rests. If any of its fundamental assumptions turn out to be questionable, the theory can hardly be expected to provide a reliable basis for analysing and responding to problems as and when they arise. For a flawed model can only provide flawed results.

Thus, a flawed model or methodology needs to be mended. That which distorts the operation of the model needs to be removed so that the analytical framework may once again provide reliable results to its users. ${ }^{16}$

The main reason for the inability of conventional economic theory to generate credible responses to the major economic problems confronting mankind is that the model that has been and continues to be used for the purpose of analysis contains precisely such a flaw (anomaly).

This flaw is the assumption that interest as an incentive for productive activity and allocating resources efficiently is no different from profit. A closer look at interest, however, shows that this is far from the case.

One consequence of this analytical faux pas is not only misunderstanding in economic theory, but also inefficiency in the way resources are allocated. Thus, the assumption that interest is no different from profit needs to be looked at, as there is evidence that it is causing significant problems both in theory and in practice. As the challenge is as much theoretical as it is practical, economic theory itself will need to be restructured first to bring it in line with reality.

Despite glaring "realities on the ground," however, economic theory remains unaware of the adverse effects of interest and continues to maintain, despite evidence to the contrary, that interest-based financing allocates resources efficiently.

\section{Rationing of capital theory}

The claim that interest-based lending helps to allocate resources efficiently is based on the "rationing of capital" theory. ${ }^{17}$ According to this view, interestbased lending helps allocate resources (capital) efficiently because it provides funds only to enterprises that can afford to pay the asking rates of interest. 
In other words, only companies that earn profits large enough to repay loans with interest in the agreed upon time period become eligible for loan financing. To put it differently, interest-based financing excludes from access to loan capital all companies whose expected profit rates fall short of the rates required to repay both principal and interest over the term of the loan.

It is not enough for businesses to earn rates of profit on borrowed capital that exceed the lending rates. They need to earn profits that will enable them to repay the principal during the amortisation period.

Thus a business that borrows $\$ 100,000.00$ over a ten-year period at $8 \%$ interest rate needs to earn approximately $14.5 \%$ profit rate on the money borrowed if it is to repay the entire loan over a ten-year period with a total of 120 repayments. Yet the average return on equity in developed nations is approximately $13 \%$, which is below the level of profits required used in our example.

Another problem with the "rationing of capital" theory is that it identifies profitability with efficiency. As is well known, the most profitable companies are not necessarily also the most efficient. Every monopoly is highly profitable yet by no means efficient. Monopolies gain higher profits by raising prices and reducing output. They are able to do this because they face no competition.

Conversely, slim profits do not necessarily indicate inefficiency. Every small or medium sized business that operates in a highly competitive environment is likely to have small profits, precisely because it operates in a highly competitive environment. Under the logic of the "rationing of capital" theory, monopolies (de facto the least efficient businesses) are the first to qualify to borrow capital, while the most efficient businesses, the SMEs, are the last, if they qualify at all.

In addition, borrowers need to post acceptable collateral, which few small and medium sized businesses can provide. This is another reason why small and medium enterprises, to say nothing of start up businesses, are often excluded from loan financing. Yet the SMEs provide most of the jobs in the modern economy. ${ }^{18}$ In this way, the results of withholding capital from SMEs include reduced investment and higher unemployment.

\section{Equity and loan financing}

Investment can be financed by means of investment for profit (risk sharing) or by means of loans (borrowing at interest). The first is interest-free and permitted; the latter uses interest to reward providers of capital and is therefore proscribed.$^{19}$

Equity and loan financing affect businesses (at the microeconomic level) as well as entire economic systems (at the macroeconomic level) in different ways. In the case of equity financing these effects are positive; in the case of loan financing, they are adverse. ${ }^{20}$ 
Parties that provide capital to businesses in the equity (share) markets are investors. Parties that offer capital in the credit markets are lenders. Investors and lenders participate in economic activity in significantly different ways.

The investor is an active participant that takes risk and therefore responsibility for his decisions. The lender by contrast is a passive supplier of capital, who takes little or no risk, and therefore no responsibility for the relative success or failure of the enterprises he helps to finance. In the case of investors, the objectives of entrepreneurs and financiers coincide; in the case of lenders, they diverge.

Common shares are asset-backed securities. The nominal price of a share is equal to the net worth of a company (total assets - total liabilities) divided by the total number of shares. The value of a share does not include any liabilities in the form of debt, as these are excluded from the calculation of the net worth of the company when debts are subtracted from the assets of the company. ${ }^{21}$

As a rule, financing by means of shares or participatory sukuk is conducive to an efficient allocation of resources. "Efficiency" here refers to the allocation of resources over the longer term in ways that meet society's needs without causing lingering shortages and surpluses.

Financing by borrowing at interest, by contrast, is far from efficient in this way. On the contrary, financing using interest-based loans reduces the efficiency with which resources are allocated. This is evident from the shortages and surpluses caused by financing investment using collateralised interest-based lending.

At the business level, equity financing has significant advantages over loan financing. First, it does not require entrepreneurs to go into debt. Second, equity financing requires providers of capital (investors) to share risks with the entrepreneurs. This shields entrepreneurs from having to shoulder all the risks of a business enterprise.

The risk of losses provides investors with an incentive to exercise due diligence, something that cannot always be taken for granted in collateralised lending. Exercising due diligence increases the efficiency of the allocation of resources, as projects with poor prospects are unlikely to attract funding.

Only credible business proposals will be able to attract funding. This helps to prevent waste and thus to increase efficiency in the use of resources. Moreover, because it requires capital providers to share the risks of business enterprise with entrepreneurs, equity financing is also more just than lending at interest.

Financing on the basis of risk sharing also brings significant benefits at the macroeconomic level. These include higher levels of employment resulting from an increase in investment; reduced cyclical instability due to lower financing using money "created" by financial institutions, and reduced inflation caused by lower prices. ${ }^{22}$ Thus, for the purpose of public policy, it is advisable to promote 
risk sharing as the choice means of financing, while at the same time phasing out financing expenditure by borrowing at interest.

\section{Markets and efficiency}

A market is an institution for buying and selling. There are as many markets as there are products, services or resources. They include producer, consumer and capital markets. Governments provide public goods and services, such as public transportation, education, welfare and medical care.

Markets facilitate the trading of goods, services and resources. Resource markets comprise human, natural and financial markets. The latter comprise equity and credit markets. Assets (company shares) are traded in the stock markets, while liabilities (loans) are traded in the bond markets. Equity markets comprise share (stock) and Islamic sukuk markets.

Efficiency is an attribute of workers, businesses or entire economies. Efficiency means productivity. Thus, a productive worker is an efficient worker. Similarly, a productive business is an efficient business. A productive economic system is an efficient system. Efficiency understood as "productivity" can be thought of as the "narrow" or technical meaning of efficiency.

The term efficiency, however, is used in one other sense in economics. The term efficiency is also used to refer to the way resources are allocated in a given economic system. If resources are allocated without generating any lasting shortages of surpluses, they are said to be allocated efficiently. If resources are allocated in ways that cause either shortages or surpluses, they are said to be allocated inefficiently.

In other words, a shortage or a surplus indicates inefficiency. It indicates inefficiency in the sense that either too few or too many resources are allocated to the production of a given product. This meaning of efficiency can be thought of as the "broad" meaning of efficiency.

In finance, however, the term "efficiency" has come to be understood differently from the way it has "traditionally" been understood in business or economics. In finance, efficiency signifies neither productivity nor the way resources are allocated. Rather, efficiency has come to be seen as an attribute of markets.

However, in so far as markets do not produce anything, characterising markets as "efficient" or lacking in efficiency seems rather odd. A market is an institution. It is not a factor of production. ${ }^{23}$ Markets facilitate the exchange of goods, services, and resources. Thus, one may well ask, what is the basis of describing markets as "efficient" in the discourse of finance? ${ }^{24}$

Nevertheless, while markets can hardly be viewed as "efficient" in the narrow sense of the term, one could perhaps argue that markets are "efficient" - or at 
least contribute to efficiency - in the broad sense of the term. In other words, one could still argue that markets are efficient in the sense that they allocate resources where they are needed most, without causing lasting shortages or surpluses.

However, in finance, markets are not seen as "efficient" in this sense either. Rather, in finance, markets are seen as "efficient" because they indicate the prices of securities (stocks and bonds) accurately.

This understanding of "efficiency" represents a significant departure from the way this term is understood in economics. Perhaps one could say that it indicates a shift of perspective from that of an economist to that of a trader.

The characterisation of financial markets as "efficient" in this way is unusual not only because markets are "traditionally" not seen in terms of "efficiency." It is also unusual because markets are generally viewed in terms of the relative freedom that may or may not prevail in a given market.

"Market freedom" means in particular freedom from government intervention. The freedom of enterprise (participating in business activity) enables markets or rather the market system as a whole to channel resources to where they are most in demand, and do so without causing any persistent shortages or surpluses. Markets do this better when they are free than when they are regulated. In this sense, "free" markets may be said to contribute to an efficient allocation of resources, in the "broad" sense of the term.

Markets channel resources to where they are most in demand. They do this by indicating, by means of the price mechanism, where higher profits may be earned. In other words, other factors being constant, changes in prices signal changes in profitability. Rising prices indicate rising profits while falling prices indicate declining profits.

The claim that markets are "efficient" is likely to give the impression that all markets - including credit markets - are efficient. Moreover, it is likely to give the impression that markets are efficient not only in the sense in which this term is used in finance but also in the sense in which it is used in economics.

On the contrary, evidence shows that unlike real sector markets, credit markets are efficient neither in the sense in which this term is used in finance nor even in the sense in which this term is used in economics.

In other words, credit markets neither determine process accurately nor allocate resources efficiently. The view that markets are efficient was first given prominence by Eugene Fama in the so-called efficient market hypothesis (EMH).

\section{Efficient market hypothesis (EMH)}

The view that "markets are efficient" is known as the "efficient market hypothesis" (EMH). It was espoused by Eugene Fama in the 1960s. ${ }^{25} \mathrm{He}$ derived 
his hypothesis from a study of share markets, and later extended it to the bond (credit) markets.

According to Fama, markets are efficient because they indicate prices of financial securities, stocks and bonds, accurately. The reason why markets indicate prices accurately is that, over the longer term, markets take into account all available information. This means that there can be no substantial difference between the price of a security and its "real" value over the longer term.

The view that markets are "efficient" emerged at a time known as "financialisation." 26 Financialisation was part of a larger trend, market liberalisation. This trend itself has been part of a larger movement towards liberalism, the ideology that views individual "freedom" as the single most important characteristic of a well-governed system. ${ }^{27}$

Liberalisation of commercial activity was undertaken in the conviction that markets were capable of regulating themselves. In general, it was expected that deregulation would increase both productivity and growth. It was believed that freer markets would enable a more efficient allocation of resources.

Thus, the often-repeated mantra that "markets are efficient" could also be seen as a plea to keep markets "free," free in particular from government regulation. Less regulation would make it possible for traders to take greater risks, and thereby gain potentially higher returns.

It appears that the argument that markets should be left to "regulate themselves" found favour among the regulatory authorities. Later events, however, would throw a different light on the experiment with the wholesale deregulation of financial markets that took place in the years leading up to the most recent (2007) financial crisis. ${ }^{28}$

The first consequence of deregulation was an increase in speculation. One perception that fuelled the rise of speculation was the perception - alleged or real - that higher returns could be earned in the financial sector than in the real sector.

Accordingly, resources in the capital markets shifted from financing productive activity in the real sector (share) markets to supporting speculative activity in the credit markets.

While benefiting some companies - financial institutions in particular deregulation had an adverse impact on economic activity by impairing overall efficiency in the allocation of resources. This was evident in the build up of indebtedness and threats to the stability of the financial system as a whole. ${ }^{29}$

A significant amount of resources was diverted from the real sector, where production takes place, to the financial sector, where speculation is the dominant activity. This "transformation" was facilitated by changes in the law. The changes invariably favoured the banking sector over the real sector. ${ }^{30}$

As a consequence of financialisation, the proportion of loans compared to 
equity financing in the capital structure of corporations increased dramatically. In the developed world, approximately two thirds of corporate financing takes place by means of loans.

The transformation of the economy from production to speculation resulted in the migration of capital from the real sector to the financial. The difference between a businessman and a speculator is that while a businessperson is willing to invest over the longer term, the speculator seeks short-term gains.

Deregulation encouraged a dramatic increase in lending, speculating on changes in interest rates by means of interest rate swaps, and betting on the possibility of loan defaults by means of credit default swaps. These developments increased levels of debt, heightened risks, and threatened systemic stability.

In the absence of market or regulatory failure, and over the longer term, share markets are efficient both in the sense in which this term is used in finance, as well as in the sense in which it is used in economics. They both determine prices accurately and allocate resources efficiently in the broad sense of the term, without causing long-term surpluses or shortages.

Evidence shows that, unlike share markets, credit markets are efficient neither in the sense in which this term is used in economics, nor in the sense in which this term is used in finance. In other words, credit markets neither allocate resources efficiently, nor determine prices accurately.

Evidence of inefficiency of the credit markets in the sense in which this term is used in finance, of determining prices accurately, was provided by the dramatic collapse of the prices of securities, in particular collateralised debt obligations or CDOs.

The inefficiency of the credit markets, in the sense in which this term is used in economics, has been confirmed by the surplus of houses financed by means of subprime mortgages. These mortgages were sold to institutions such as pension funds and insurance companies in the form of collateralised debt obligations (CDOs). ${ }^{31}$

In the US, after being repossessed by financial institutions due to defaults by house buyers, these surplus properties were subsequently demolished due to dilapidation. ${ }^{32}$ Similarly, overinvestment also took place in the property market in Dubai, using similar, debt-like instruments of financing.

The inefficiency caused by credit financing is due to the fact that rewards to capital providers (lenders) are not linked in any meaningful way to the profitability of the businesses financed with loans. Rewards to lenders (payments of interest or equivalent) are not determined as a proportion of the total profits earned but rather as a proportion of the total amount of capital provided (loaned). This gives the capital providers little incentive to allocate resources to the most profitable uses. 
At the basic level the inefficiency of credit markets stems from the fact that lenders can obtain rewards without being required to make a real contribution to production. As long as any party is able to claim income without making a direct contribution to production, inefficiency will persist in one way or another.

\section{Conclusions and Recommendations}

It needs to be recognised that credit markets do not operate in the same way as equity or share markets. Activity in these markets is driven by different incentives, interest on the one hand, and wages, rents and profit on the other. Interest and profit in particular have radically different effects on how resources are allocated.

One incentive (profit) is conducive for ensuring that resources will be allocated efficiently. The other (interest) is not. Borrowers need to guarantee both principal and periodic payments to creditors. Entrepreneurs need to guarantee neither.

The amount of waste caused by interest-based lending can be ascertained by identifying the total amount of interest paid out to all lenders in a given year by all borrowers. In a typical developed country, the amount of interest paid as a component of national income ranges from 8 to $11 \%$ of total GDP.

It goes without saying that in any economic system where it would be illegal to gain interest income, and where income could only be earned in the form of wages, rents and profits, the real GDP could be expected to increase approximately by the amount of money currently paid out to lenders by borrowers, in other words by approximately 8 to $11 \%$ per annum.

To eliminate the inefficiencies spawned by financing investment by lending at interest, a different mode of financing needs to be utilised. A mode of financing needs to be implemented where rewards to the providers of capital depend directly on the performance of the productive assets they finance.

Suppliers and managers of capital share both risks and rewards. This is in keeping with the requirements of ethics. The transition from debt to equity financing can take place in stages. It can be facilitated by suitable legislative changes.

When risk sharing takes the place of lending at interest, major inefficiencies caused by interest-based financing should be overcome. In addition, one can expect reductions in the levels of debt, the freeing of government resources for spending on social services, higher employment, lower inflation, higher growth and greater systemic stability - at the same time.

The realisation of efficiency in the allocation of resources presupposes meeting a number of conditions. This includes the need to restructure the system of incentives. In particular, there is a need to implement a regulatory framework and a system of incentives that reward real investment (production 
of wealth) rather than speculation (transfer of wealth) such as takes place in the trading of bonds in the debt markets.

This requires supplanting lending at interest with financing on the basis of risk sharing. Incentives need to be put in place to foster productive activity and to discourage unproductive speculation, in particular in the credit markets.

Thus it is the problem of interest that needs to be addressed first. Interest is an anomaly of sorts within the economic system. It was not always entrenched within the economic system to the same extent as it is in the modern economy.

Thus, what is required is a paradigm shift, from an economy that is driven by incentives that includes not only incentives in the form of wages, rents and profits but also interest, to an interest-free economy. ${ }^{34}$

- It is recommended that economic theory be restructured in a way that eliminates interest from the theoretical framework, as an incentive for rewarding participation on commercial activity.

- Courses in economics should incorporate modules that highlight differences between interest and profit and outline the effects each has on different aspects of economic activity.

- Economic analysis needs to highlight the differences between credit and real sector markets and the effects each have on the efficiency of the location of resources.

- It is recommended that suitable incentives, both legal and tax, be provided to spur the utilisation of risk sharing modes of financing.

\section{Notes:}

* Abdul Karim Abdullah (Leslie Terebessy), Assistant Fellow at IAIS, earned his MA in political philosophy from the University of Toronto, Canada (1999) and a MEd (1986) from the University of Toronto's Ontario Institute for Studies in Education (OISE). A former lecturer, editor, writer and coordinator of the English programme at University Sains Islam Malaysia (USIM), his current projects involve research into the current financial crisis, critical thinking in Muslim societies, and Islamic Finance. He has edited Islamic Studies at World Institutions of Higher Learning (Kuala Lumpur: USIM 2004). He can be contacted at abdulkarim@iais.org.my.

1. This took place during the emergence of what has come to be known as European modernity. By modernity we mean primarily European modernity, or the major social, political and economic transformation that took place beginning with the Renaissance. Interest was legalised in England by Henry VIII in 1545, after he broke away from the Catholic Church a few years earlier.

2. Leigh, Daniel, Deniz Igan, John Simon, and Petia Topalova "Chapter 3: Dealing with household debt," IMF World Economic Outlook, April 2012, p. 16. Available 
online at: <http://www.imf.org/external/pubs/ft/weo/2012/01/pdf/c3.pdf>

3. Interest is typically "compounded," which means borrowers effectively pay interest not only on the original amount borrowed, but also on any interest added to the original amount.

4. See Abdul Karim Abdullah "Debt and Economic Activity," ICR, Vol. 4, No. 3, July 2013.

5. The yield on Greek government bonds "reached almost $40 \%$ at the beginning of March 2012." Greenlaw David, James D. Hamilton, Peter Hooper, Frederic S. Mishkin, "Crunch Time: Fiscal Crises and the Role of Monetary Policy," paper written for the U.S. Monetary Policy Forum, New York City, 22 February 2013, p. 33. Available online at: <http://research.chicagobooth.edu/igm/usmpf/file. aspx>

6. Perkins, John Confessions of an Economic Hitman, Ebury Press, UK, 2006, p. 218.

7. Dent, Harry S. Jr. and Rodney Johnson The Great Crash Ahead, Free Press, New York, 2011, pp. 182-200.

8. See Abdul Karim Abdullah "Restoring the Ethical Basis of Finance" ICR, Vol. 5, No.1 January 2014.

9. See Abdul Karim Abdullah "Enhancing Cyclical Stability by Interest-free Banking” ICR, Vol. 5, No. 3, July 2014.

10. This is already taking place in some sectors, such as the furniture market, but needs to be extended to other sectors as well, for example housing. Some manufacturers of furniture, such as IKEA, already offer interest-free financing to households that are not able to pay in cash but can only afford to purchase furniture on an installment (credit) basis. No interest is added to the price of the furniture thus purchased on an installment basis.

11. See http://www.ikea.com/ms/en_SG/customer_service/ikea_services/interest_ free/\#.

12. As one observer noted, "interest on debt is one of the world's most powerful instruments for redistributing wealth from the poor to the rich." Anielski, Mark 2004: "Genuine Wealth and the Good Life," article originally written for the publication in the Summer 2004 edition of YES! A Journal for Positive Futures on the subject of "The Good Life," p. 2. Available online at: $<$ http://www. anielski.com/old_site/Documents/Anielski\%20Good\%20Life.pdf>

13. See Abdul Karim Abdullah "Understanding the Causes of the Debt-Crisis: Interest-based lending," ICR, Vol. 3, Number 4, July 2012.

14. Brown, Ellen, Hodgson, The Web of Debt, Third Millennium Press, 2008, p. 368.

15. See Abdul Karim Abdullah "The Pitfalls of Riba or Interest-based Financing," ICR, Vol. 4, No. 1, Jan. 2013.

16. The process is similar to that described by Thomas Kuhn in his acclaimed work. See Kuhn, Thomas S. The Structure of Scientific Revolutions, $50^{\text {th }}$ anniversary, Ian Hacking (Intro.) (4 $4^{\text {th }}$ ed.,) The University of Chicago Press, 2012.

17. See for example McConnell R. Campbell and Stanly L. Brue Economics, McGraw-Hill Inc., New York, 1996, pp. 485-<http://www.ikea.com/ms/en_SG/ customer_service/ikea_services/interest_free/\# 486>

18. "SMEs today account for more than $\overline{9} 8$ per cent of Europe's business and provide more than 67 per cent of jobs in the union which makes them the most 
important drivers of European long-term economic growth and sustainable job creation. A recent study by the European central bank reported a deterioration in the availability of bank loans ... for eurozone SMEs applying for a loan." De Backer, Philippe "SMEs crucial to Europe's economic and job stability," The Parliament, 27 September 2014, available online at: <https://www. theparliamentmagazine.eu/articles/opinion/smes-crucial-europe $\%$ E2\%80\%99seconomic-and-job-stability>

19. Qur'an, 2:275--280.

20. See Abdul Karim Abdullah "Economic Benefits of Risk Sharing," ICR, Vol. 5, No. 4, October 2014.

21. Thus there is no need to worry that when common shares are traded debt is also traded. All debt is automatically subtracted from the values of the share, as all liabilities are subtracted from the total assets of the company to determine the book value of the share.

22. Robert Skidelsky, in Skidelsky, Robert and Christian Westerlind Wigstrom, The Economic Crisis and the State of Economics, Palgrave Macmillan, 2010, p. 8.

23. For a novel treatment of markets, see McNally, David Monsters of the Market, Haymarket Books, Chicago, 2012.

24. One may note in passing that money, used for the purpose of making transactions in markets, is not a factor of production either, as money by itself does not produce anything. Thus, the payment of interest for the use of someone's money cannot be justified by the claim that the lender is entitled to be compensated for the use of his or her money by the borrower.

Compensation for the use of money can, however, be justified if an additional condition is satisfied, which is that the capital provider takes risk. Taking a risk merits being compensated for the use of one's capital.

Investors take risk when they invest in ordinary shares or asset-backed sukuk. By contrast, no risk to creditors is present in any agreement where borrowers are required to guarantee both the principal amount of the loan as well as the interest. One may additionally note that time is not a factor of production either. At best, time can be seen as a condition of production. It can be seen as a condition of production in the sense that all production takes place over time.

The payment of interest cannot be justified by claiming that it is payment for time either. The reason is that time is neither a commodity nor a service that can be "traded" in a market. In any case, time is not the lender's to sell.

25. Fama, Eugene F. and French, Kenneth R. "Common Risk Factors in the Returns on Stocks and Bonds," Journal of Financial Economics Vol. 33 (1), pp. 3-56, 1993.

26. Foster, John Bellamy "The Financialization of Capitalism," Monthly Review, Issue 11 (April), Volume 58, 2007. Available online at: <http://monthlyreview. org/2007/04/01/the-financialization-of-capitalism>

27. While freedom is necessary to protect the dignity of the individual, freedom is not without limits. This is recognised by the fact that even the freest nations impose restrictions on freedom in various ways.

Some restrictions thus need to be placed on freedom, if for no other reason than to prevent abuses. Life with dignity itself is hardly possible without differentiating acts that contribute to well-being from those that undermine it. The prohibition of interest is a case in point. 
Seen in a broader context, the legalisation of interest was part of a liberal trend that swept Europe during the sixteenth and seventeenth centuries. It was also to a degree a result of a new confidence, perhaps not entirely warranted, in the power of human reason to legislate in the area of ethics, traditionally a preserve of religion.

The legalisation of interest was a part of a moral revolution, which took place in part by drifting away from revelation as a source of guidance. During this upheaval, individual autonomy became more prominent and the state was expected to protect it.

The liberation of modern man from the restraints "traditionally" imposed on human initiative by the need to conform to the requirements of religion was justified by appealing to the doctrine of human rights. However, it appears that in the haste to recognise and protect human rights, the need to maintain consciousness of human obligations appeared to have taken a back seat.

28. Rogoff, Kenneth S. \& Carmen M. Reinhart This Time Is Different, Princeton University Press, 2009, p. 208.

29. See Roubini, Nouriel and Stephen Mihm Crisis Economics, Penguin Books, New York, 2010.

30. Financialisation is a global phenomenon. According to the World Bank, the global volume of financial transactions is approximately 15 to 20 times greater than what is required to finance world trade. Kennedy, Margrit, Interest and Inflation Free Money, Seva International, 1995, p. 10. Available online at: $<$ http://userpage.fu-berlin.de/ roehrigw/kennedy/english/Interest-and-inflationfree-money.pdf $>$

31. Hammond, Jeremy R. Ron Paul vs. Paul Krugman, n.a. 2012, p. 48.

32. "Since 2007, banks have foreclosed around eight million homes. It is estimated that another eight to ten million homes will be foreclosed before the financial crisis is over." Currently there are 18.6 million unoccupied houses in the US. That is approximately 6 houses for each of the 3.5 million homeless persons. The National Economic and Social Rights Initiative, The Mind Unleashed, 2014. Available online at: <http://themindunleashed.org/2014/02/18600000-vacanthomes-united-states-enough-every-homeless-person-six.html>

33. See Abdul Karim Abdullah "Risk Sharing, Transfer and Management," ICR, Vo. 4, No. 2, Apr. 2013.

34. One may note in passing that in the discourse on sustainable development, little attention is being accorded to ensuring that financing of development itself will be sustainable.

This is especially worrying in light of the fact that estimates show that anywhere from 3.5 to 5 trillion dollars per year will be required to finance development over the next fifteen years. The need to pay attention to the sustainability of finance shows up dramatically in the issue of indebtedness, especially by poorer nations. Let us hope that "development" will be sustainable not only in terms of the impact on the environment, but also from the financial point of view, in terms of the impact on the people that will, in the final analysis, have to pay for it. 